\title{
Pharmacological and Non-pharmacological Treatments of Irritable Bowel Syndrome and Their Impact on the Quality of Life: A Literature Review
}

Reham Gendi ${ }^{1}$, Nusrat Jahan ${ }^{1}$

1. Internal Medicine, California Institute of Behavioral Neurosciences \& Psychology, Fairfield, USA

Corresponding author: Reham Gendi, rehamgendi@yahoo.com

\begin{abstract}
Irritable bowel syndrome (IBS) is a non-organic gastrointestinal disorder that adversely affects the quality of life (QoL). The etiology of the disease is not fully understood, and appropriate treatment is still a matter of debate. Therefore, we feel that a review that describes the different treatment methods of treatment is needed to provide the correct clues. A comprehensive literature search was performed on PubMed, including randomized clinical trials and review articles. We carefully reviewed the different treatment options mentioned in the published research papers and compared their results to address the treatment options for IBS. The current literature review reveals that pharmacological treatments such as antidepressants, vitamin $\mathrm{D}$, probiotics, and antispasmodic drugs and non-pharmacological treatments including cognitive-behavioral therapy (CBT), acupuncture, anise, and diet modification can help control the symptoms of IBS and improve the QoL of patients.
\end{abstract}

Categories: Internal Medicine, Psychology, Gastroenterology

Keywords: irritable bowel syndrome, physiology, pathology, epidemiology, psychology, therapy

\section{Introduction And Background}

Irritable bowel syndrome (IBS) is a non-organic gastrointestinal disorder that has a negative impact on the quality of life (QoL). Currently, the diagnosis of IBS is based on new Rome IV criteria as a recurring abdominal pain related to two or more of the following conditions: defecation-related, associated with an increase in the stool frequency, and associated with a disparity in stool quality [1]. Symptom onset should occur at least six months before the diagnosis, and symptoms should be presented in the last three months, on average, and at least one day in a week.

Received 01/16/2020

Review began 03/26/2020 Review ended 04/08/2020 Published 07/21/2020

\section{() Copyright 2020}

Gendi et al. This is an open access article distributed under the terms of the Creative Commons Attribution License CC-BY 4.0., which permits unrestricted use, distribution, and reproduction in any medium, provided the original author and source are credited.
The prevalence of IBS is approximately 9-23\% worldwide, with a devastating impact on the QoL. Hence, we wanted to find out if IBS could be associated with psychological problems. The currently available treatment options, both pharmacological and non-pharmacological, can help in controlling symptoms. However, a knowledge gap still exists. We aim to find the best possible treatment options for IBS, which would help to treat this condition and improve the QoL for patients.

\section{Mechanism of IBS}

IBS symptoms have unclear etiology, and there is no specific treatment available to treat IBS patients. Recent studies show that symptoms of IBS most likely occur due to the gut-brain axis imbalance as evidenced by increased abdominal pain during periods of stress. Stress can cause a change in intestinal motility and permeability along with microbiota imbalance as some cases developed IBS due to alteration of the gut microbiota as a result of an infection [1,2-10]. In contrast, some believe it to be mostly caused by psychological disorders. According to Spiller et al., at least $50 \%$ of the IBS patients can be described as depressed, anxious, or hypochondriacs and over $60 \%$ of IBS patients receiving tertiary care had presented with a psychiatric disorder, most commonly depression, anxiety, or both [11].

\section{Psychological disorders and their relation to IBS}

Stress can modify and exacerbate central pain circuity and, therefore, it may be related to the development of visceral pain, which is related to IBS. A study has shown that IBS could be related to mental disorders as about $50-90 \%$ of IBS patients meet the criteria of psychiatric disorder, mainly anxiety, panic disorder, and major depressive disorder [12]. Another study has shown that catastrophizing, which is defined as expecting a negative outcome, is more common in IBS patients [13]. Hence, IBS can be associated with paincatastrophizing thinking with a propensity to magnify the seriousness of the illness.

\section{Treatment options}




\section{Cureus}

We are currently aware of the multi-systemic reasons behind the occurrence of IBS symptoms and the role of psychological disorders in its development or exacerbation. However, it needs to be further established as to how psychological treatment plans can be used as an effective way to resolve IBS symptoms. This psychosomatic visceral pain link can help us to illustrate several treatments that can help reduce symptoms in patients with IBS and improve their QoL.

The objective of this review is to focus on the treatment options for IBS and the effect of using different interventions to control IBS symptoms. It compares various studies discussing cognitive behavioral therapy (CBT), antidepressants, probiotics, anise, acupuncture, vitamin D, and diet modification as management options for IBS. The literature review aims to provide an insight into current treatment options for controlling IBS symptoms and improving the QoL.

\section{Review}

\section{Materials and methods: data collection}

The data were collected from PubMed using Medical Subject Headings (MeSH) keywords "Irritable bowel syndrome, physiology, pathology, epidemiology, psychology, and therapy." The following inclusion criteria were applied in the order given; clinical trial and review studies, articles involving only human subjects, articles published in English only, and those involving subjects aged 19-44 years. The collection of the articles for the study was done in an ethical manner.

\section{Results}

Using MeSH keywords on PubMed, a total of 5,780 papers were collected, of which 651 were used for filtering. The details of the articles obtained by applying MeSH keywords and inclusion criteria in PubMed are given below (Table 1).

\begin{tabular}{|l|l|}
\hline Articles & Results, $\mathbf{n}$ \\
\hline Total article found on PubMed & 13,950 \\
\hline Articles obtained with MeSH keywords & 5,780 \\
Clinical trials and reviews & 2,221 \\
Human subjects & 2,215 \\
\hline English language & 1,976 \\
\hline Subjects aged 19-44 & 651 \\
\hline
\end{tabular}

\section{TABLE 1: Article search results on PubMed}

Each of the 651 studies identified was evaluated individually based on the abstract. Among them, 163 articles were nonduplicated, and 67 were found to be non-relevant while screening the abstracts. Another 12 articles were excluded after the full-text screening since the patient age was out of the age range for our study. And one more article was removed during data extraction as it was a systemic review that included different age groups.

Finally, 83 relevant articles were chosen for this review article. The current literature review analyzes a total of 16 full-text articles that study different treatment options for controlling IBS symptoms.

\section{Discussion}

Although IBS is not a life-threatening condition, it puts a heavy burden on healthcare resources. Treating a patient for one year costs around $\$ 355-3,344$, and the condition has a very drastic effect on the QoL of patients [14]. The condition has an unknown mechanism, and it has been found to alter intestinal motility and cause stress and microbiota imbalance, which explains the treatment options available now $[1,2-10]$. In this review, we included 83 papers on PubMed, which addressed the various treatment options available for IBS. We also engage in a comparison of these studies.

It has been found that many IBS patients respond to treatment to some extent. However, others do not due to various factors or the disparity in severity. In light of this, we review both pharmacological and nonpharmacological treatments that aimed to provide the best control of IBS symptoms and their effects on 


\section{Cureus}

QoL. Our review aims to provide a complete overview of these treatment options to determine their efficacy in treating IBS in light of these previous studies.

Effect of Cognitive Behavioral Therapy on IBS

One study has discussed cognitive behavioral therapy (CBT) as a treatment option for controlling IBS symptoms compared with other possibilities as an educational exercise [15]. Another one has discussed its mechanism by drawing a connection between emotion, behavior, and cognition as a treatment option for IBS [16]. Overall, all these studies generally endorse using CBT for IBS (Table 2).

\begin{tabular}{|c|c|c|c|c|}
\hline Study & $\begin{array}{l}\text { Author } \\
\text { name/year }\end{array}$ & $\begin{array}{l}\text { Study } \\
\text { design }\end{array}$ & Sample size & Main points \\
\hline $\begin{array}{l}\text { Study } \\
1\end{array}$ & $\begin{array}{l}\text { Lackner et } \\
\text { al./2018 [15] }\end{array}$ & $\begin{array}{l}\text { Randomized } \\
\text { controlled } \\
\text { trial }\end{array}$ & 436 patients & $\begin{array}{l}\text { The study compared CBT vs. education in the treatment of IBS. Patients were } \\
\text { more responsive to CBT than education for IBS symptoms control }\end{array}$ \\
\hline $\begin{array}{l}\text { Study } \\
2\end{array}$ & $\begin{array}{l}\text { Reme et } \\
\text { al./2011 [16] }\end{array}$ & $\begin{array}{l}\text { Randomized } \\
\text { controlled } \\
\text { trial }\end{array}$ & 149 patients & $\begin{array}{l}\text { This study supports that CBT has a positive impact on IBS symptoms due to } \\
\text { communication between emotion, behavior, and cognition in the development } \\
\text { of IBS }\end{array}$ \\
\hline $\begin{array}{l}\text { Study } \\
3\end{array}$ & $\begin{array}{l}\text { Jang et } \\
\text { al./2014 [17] }\end{array}$ & $\begin{array}{l}\text { Randomized } \\
\text { controlled } \\
\text { trial }\end{array}$ & $\begin{array}{l}180 \text { patients initially; } 13 \\
\text { patients withdrew during } \\
\text { the research for various } \\
\text { reasons }\end{array}$ & $\begin{array}{l}\text { The study showed the effect of CBT on IBS in female nursing students. CBT } \\
\text { proved to be effective in improving QoL and reduced the symptoms of IBS }\end{array}$ \\
\hline $\begin{array}{l}\text { Study } \\
4\end{array}$ & $\begin{array}{l}\text { Chilcot et } \\
\text { al./2013 [18] }\end{array}$ & $\begin{array}{l}\text { Randomized } \\
\text { controlled } \\
\text { trial }\end{array}$ & 64 patients & $\begin{array}{l}\text { The study showed CBT has a better effect on symptoms of IBS rather than } \\
\text { usual treatment. CBT has a positive effect on IBS due to its impact on } \\
\text { cognition rather than the mood }\end{array}$ \\
\hline $\begin{array}{l}\text { Study } \\
5\end{array}$ & $\begin{array}{l}\text { Ljótsson et } \\
\text { al./2013 [19] }\end{array}$ & $\begin{array}{l}\text { Randomized } \\
\text { controlled } \\
\text { trial }\end{array}$ & 195 patients & $\begin{array}{l}\text { This study compared the impact of internet } \mathrm{CBT} \text { and stress management on } \\
\text { improving IBS symptoms. Internet CBT has a positive effect on IBS symptoms } \\
\text { due to its ability to reduce gastrointestinal anxiety and not due to stress } \\
\text { reduction }\end{array}$ \\
\hline $\begin{array}{l}\text { Study } \\
6\end{array}$ & $\begin{array}{l}\text { L Ljotsson et } \\
\text { al./2010 [20] }\end{array}$ & $\begin{array}{l}\text { Randomized } \\
\text { controlled } \\
\text { trial }\end{array}$ & 85 patients & $\begin{array}{l}\text { This study examined the role of CBT in developing mindfulness and exposure } \\
\text { offered by the internet in controlling IBS symptoms. It showed that CBT via the } \\
\text { internet is beneficial for controlling IBS symptom and improving patients' QoL }\end{array}$ \\
\hline
\end{tabular}

TABLE 2: Studies that discuss the effect of CBT on IBS

CBT: cognitive behavioral therapy; IBS: irritable bowel syndrome; QoL: quality of life

Effect of Anti-psychological Pharmacological Treatment on IBS

Antidepressants and antipsychotic medications can be a treatment option for IBS. Many of the studies illustrate that some of these drugs, such as duloxetine, have shown a positive effect on patients with generalized anxiety disorder (GAD) along with IBS [21]. Tianeptine and amitriptyline have a positive impact on irritable bowel syndrome with diarrhea (IBS-D) [22]. Imipramine can also be used to treat IBS [23]. One study showed that citalopram could be useful while another study questioned this conclusion; both studies discussed the effect of citalopram on IBS symptoms away from its impact as an antidepressant (Table 3). 


\section{Cureus}

\begin{tabular}{|c|c|c|c|c|}
\hline Study & $\begin{array}{l}\text { Author } \\
\text { name/year }\end{array}$ & Study design & $\begin{array}{l}\text { Sample } \\
\text { size }\end{array}$ & Main points \\
\hline $\begin{array}{l}\text { Study } \\
1\end{array}$ & $\begin{array}{l}\text { Kaplan et } \\
\text { al./2013 [21] }\end{array}$ & Pilot study & $\begin{array}{l}13 \\
\text { patients }\end{array}$ & $\begin{array}{l}\text { This study analyzes the effect of duloxetine in } 13 \text { patients with GAD and IBS. It found that } \\
\text { duloxetine has a positive impact on IBS and GAD symptoms }\end{array}$ \\
\hline $\begin{array}{l}\text { Study } \\
2\end{array}$ & $\begin{array}{l}\text { Sohn et } \\
\text { al./2012 [22] }\end{array}$ & $\begin{array}{l}\text { Randomized } \\
\text { clinical trial }\end{array}$ & patients & $\begin{array}{l}\text { This study compared the effect of tianeptine with amitriptyline on IBS. It used both } \\
\text { medications in addition to probiotic. it concluded that both can improve IBS-D, but the } \\
\text { side effects of tianeptine limit its use }\end{array}$ \\
\hline $\begin{array}{l}\text { Study } \\
3\end{array}$ & $\begin{array}{l}\text { Abdul-Baki } \\
\text { et } \\
\text { al./2009 [23] }\end{array}$ & $\begin{array}{l}\text { Randomized, } \\
\text { double-blind trial }\end{array}$ & $\begin{array}{l}56 \\
\text { patients }\end{array}$ & $\begin{array}{l}\text { Imipramine has a positive impact on IBS symptoms compared to placebo. It assists in } \\
\text { improving QoL. Precaution by choosing the right candidate for its use is essential along } \\
\text { with starting with low dose }\end{array}$ \\
\hline $\begin{array}{l}\text { Study } \\
4\end{array}$ & $\begin{array}{l}\text { Ladabaum } \\
\text { et } \\
\text { al./2010 [24] }\end{array}$ & $\begin{array}{l}\text { Randomized } \\
\text { clinical trial }\end{array}$ & patients & $\begin{array}{l}\text { The research concluded that citalopram does not have a positive effect on IBS symptoms } \\
\text { in comparison to placebo in non-depressed patients }\end{array}$ \\
\hline $\begin{array}{l}\text { Study } \\
5\end{array}$ & $\begin{array}{l}\text { Masand et } \\
\text { al./2009 [25] }\end{array}$ & $\begin{array}{l}\text { Double-blind, } \\
\text { randomized } \\
\text { controlled study }\end{array}$ & patients & $\begin{array}{l}\text { Paroxetine has no beneficial effect on pain control in IBS, while it has a positive impact on } \\
\text { clinical global impression improvement ratings }\end{array}$ \\
\hline $\begin{array}{l}\text { Study } \\
6\end{array}$ & $\begin{array}{l}\text { Talley et } \\
\text { al./2008 [26] }\end{array}$ & $\begin{array}{l}\text { Randomized } \\
\text { controlled study }\end{array}$ & $\begin{array}{l}51 \\
\text { patients }\end{array}$ & Neither imipramine nor citalopram has a positive effect on global IBS endpoints \\
\hline $\begin{array}{l}\text { Study } \\
7\end{array}$ & $\begin{array}{l}\text { Tack et } \\
\text { al./2006 [27] }\end{array}$ & $\begin{array}{l}\text { Double-blind, } \\
\text { parallel-arm study }\end{array}$ & $\begin{array}{l}23 \\
\text { patients }\end{array}$ & $\begin{array}{l}\text { Citalopram has a positive impact on IBS symptoms. Citalopram's positive effect is not } \\
\text { related to improving depression or anxiety symptoms }\end{array}$ \\
\hline
\end{tabular}

\section{TABLE 3: Studies that discuss the effect of pharmacological treatment on IBS}

IBS: irritable bowel syndrome; IBS-D: irritable bowel syndrome with diarrhea; GAD: generalized anxiety disorder

Effect of Probiotics on IBS

One study has shown that probiotics could improve IBS symptoms, while another one has indicated that it might aggravate the IBS symptoms, specifically bloating [28,29]. We reviewed six studies relating to probiotics, and three of them showed that the probiotic effect is no stronger than that of placebo; one study showed that the probiotic effect on improving QoL is related to its impact on depression symptoms and not on IBS symptoms [30]. On the other hand, the other three showed that probiotics do have a positive effect on controlling IBS symptoms (Table 4). 


\section{Cureus}

\begin{tabular}{|c|c|c|c|c|}
\hline Study & $\begin{array}{l}\text { Author } \\
\text { name/year }\end{array}$ & $\begin{array}{l}\text { Study } \\
\text { design }\end{array}$ & $\begin{array}{l}\text { Sample } \\
\text { size }\end{array}$ & Main points \\
\hline $\begin{array}{l}\text { Study } \\
1\end{array}$ & $\begin{array}{l}\text { Ishaque et } \\
\text { al./2018 [28] }\end{array}$ & $\begin{array}{l}\text { Double-blind } \\
\text { trial }\end{array}$ & $\begin{array}{l}400 \text { IBS-D } \\
\text { patients }\end{array}$ & $\begin{array}{l}\text { Probiotic has a beneficial effect on IBS-D symptoms, including abdominal pain and } \\
\text { frequency of stool }\end{array}$ \\
\hline $\begin{array}{l}\text { Study } \\
2\end{array}$ & $\begin{array}{l}\text { Pinto- } \\
\text { Sanchez et } \\
\text { al./2017 [30] }\end{array}$ & $\begin{array}{l}\text { Randomized, } \\
\text { double-blind } \\
\text { controlled } \\
\text { study }\end{array}$ & $\begin{array}{l}44 \text { IBS-D or } \\
\text { mixed stool } \\
\text { pattern } \\
\text { patients }\end{array}$ & $\begin{array}{l}\text { Probiotic Bifidobacterium longum improves depression symptoms associated with IBS and } \\
\text { QoL, which was accompanied by a change in a brain-stimulating pattern but does not affect } \\
\text { IBS symptoms or the anxiety related to it }\end{array}$ \\
\hline $\begin{array}{l}\text { Study } \\
3\end{array}$ & $\begin{array}{l}\text { Hod et } \\
\text { al./2017 [31] }\end{array}$ & $\begin{array}{l}\text { Double- } \\
\text { blind, } \\
\text { placebo- } \\
\text { controlled } \\
\text { study }\end{array}$ & 107 patients & Probiotic $\mathrm{BIO} 25$ has the same effect on IBS-D symptoms as a placebo \\
\hline $\begin{array}{l}\text { Study } \\
4\end{array}$ & $\begin{array}{l}\text { Han et } \\
\text { al./2016 [32] }\end{array}$ & $\begin{array}{l}\text { Randomized, } \\
\text { double-blind } \\
\text { controlled } \\
\text { study }\end{array}$ & $\begin{array}{l}50 \text { IBS-D } \\
\text { patients }\end{array}$ & $\begin{array}{l}\text { The research compared the effect of a double coating or non-coating probiotic. It showed } \\
\text { that double coating probiotic relieved IBS inconvenience and can be used as a treatment } \\
\text { option for IBS-D }\end{array}$ \\
\hline $\begin{array}{l}\text { Study } \\
5\end{array}$ & $\begin{array}{l}\text { Begtrup et } \\
\text { al./2013 [33] }\end{array}$ & $\begin{array}{l}\text { Randomized } \\
\text { controlled } \\
\text { trial }\end{array}$ & 131 patients & $\begin{array}{l}\text { The research compared the effect of probiotic-containing lactobacillus Paracasei, } \\
\text { acidophilus and Bifidobacterium Bb12 to that of placebo through six months on controlling } \\
\text { symptoms of IBS. The study did not detect a positive effect of probiotic when compared } \\
\text { with placebo }\end{array}$ \\
\hline $\begin{array}{l}\text { Study } \\
6\end{array}$ & $\begin{array}{l}\text { Enck et } \\
\text { al./2009 [34] }\end{array}$ & $\begin{array}{l}\text { Double-blind } \\
\text { controlled } \\
\text { trial }\end{array}$ & 298 patients & $\begin{array}{l}\text { The study compared the effects of probiotic Symbioflor-2 (E-Coli product) with that of } \\
\text { placebo on abdominal pain score and showed that probiotic has a more significant effect } \\
\text { than placebo }\end{array}$ \\
\hline
\end{tabular}

\section{TABLE 4: Studies that discuss the effect of probiotics on IBS}

IBS: irritable bowel syndrome; IBS-D: irritable bowel syndrome with diarrhea; QoL: quality of life

Effect of Other Treatment Options on IBS

There are plenty of other treatment options that might improve IBS symptoms. These options include a low fermentable oligo-, di-, mono-saccharides, and polyols (FODMAP) diet, anise, vitamin D, acupuncture, and antispasmodic drugs [35-39]. The following table provides the details of the studies that examined the effects of each of these options on controlling IBS symptoms (Table 5). 


\section{Cureus}

\begin{tabular}{|c|c|c|c|c|}
\hline Study & $\begin{array}{l}\text { Author } \\
\text { name/year }\end{array}$ & Study design & $\begin{array}{l}\text { Sample } \\
\text { size }\end{array}$ & Main points \\
\hline $\begin{array}{l}\text { FODMAP diet } \\
\text { effect }\end{array}$ & $\begin{array}{l}\text { Eswaran et } \\
\text { al./2016 [35] }\end{array}$ & $\begin{array}{l}\text { Randomized } \\
\text { controlled trial }\end{array}$ & patients & $\begin{array}{l}\text { The study compared the use of low FODMAP diet to modified NICE diet in } \\
\text { controlling IBS symptoms and illustrated that low FODMAP diet has a significant } \\
\text { effect on controlling pain and bloating compared to a diet based on the modified } \\
\text { NICE guidelines }\end{array}$ \\
\hline $\begin{array}{l}\text { Study 2: anise } \\
\text { effect }\end{array}$ & $\begin{array}{l}\text { Mosaffa- } \\
\text { Jahromi et } \\
\text { al./2016 [36] }\end{array}$ & $\begin{array}{l}\text { Three-armed, } \\
\text { double-blind } \\
\text { clinical trial }\end{array}$ & $\begin{array}{l}120 \\
\text { patients }\end{array}$ & $\begin{array}{l}\text { The study illustrated that the anise cap has a better impact on IBS symptoms } \\
\text { improvement compared to Colpermin }{ }^{\mathrm{TM}} \text { or placebo }\end{array}$ \\
\hline $\begin{array}{l}\text { Study 3: } \\
\text { vitamin effect }\end{array}$ & $\begin{array}{l}\text { Abbasnezhad } \\
\text { et } \\
\text { al./2016 [37] }\end{array}$ & $\begin{array}{l}\text { Double-blind, } \\
\text { randomized, } \\
\text { placebo- } \\
\text { controlled trial }\end{array}$ & 90 patients & $\begin{array}{l}\text { IBS symptoms over six months. It showed that vitamin D has a more significant } \\
\text { positive impact on improving IBS symptoms }\end{array}$ \\
\hline $\begin{array}{l}\text { Study 4: } \\
\text { acupuncture } \\
\text { effect }\end{array}$ & $\begin{array}{l}\text { MacPherson } \\
\text { et } \\
\text { al./2012 [38] }\end{array}$ & $\begin{array}{l}\text { Two-arm, } \\
\text { pragmatic, } \\
\text { randomized } \\
\text { controlled } \\
\text { study }\end{array}$ & $\begin{array}{l}233 \\
\text { patients }\end{array}$ & $\begin{array}{l}\text { The study compared acupuncture with usual care used in controlling IBS } \\
\text { symptoms and illustrated that acupuncture has better results and should be a } \\
\text { treatment option for IBS }\end{array}$ \\
\hline $\begin{array}{l}\text { Study 5: } \\
\text { antispasmodic } \\
\text { effect }\end{array}$ & $\begin{array}{l}\text { Zheng et } \\
\text { al./2015 [39] }\end{array}$ & $\begin{array}{l}\text { Prospective, } \\
\text { double-blind, } \\
\text { placebo- } \\
\text { controlled trial }\end{array}$ & $\begin{array}{l}427 \\
\text { patients in } \\
\text { three } \\
\text { hospitals } \\
\text { in China }\end{array}$ & $\begin{array}{l}\text { Pinaverium has a better effect on improving IBS abdominal pain and stool } \\
\text { frequency and can be considered a first-line treatment for IBS }\end{array}$ \\
\hline
\end{tabular}

TABLE 5: Studies that discuss the effect of low FODMAP diet, anise, vitamin D, acupuncture, and antispasmodic drugs on IBS

FODMAP: fermentable oligo-, di-, mono-saccharides, and polyols; IBS: irritable bowel syndrome; IBS-D: irritable bowel syndrome with diarrhea; NICE: National Institute for Health and Care Excellence

\section{Limitation of the study}

Our literature review has some limitations. The study is limited in its analysis in terms of patient age (all patients involved were $<45$ years old) and does not include observational and non-randomized clinical trials. More studies are needed to explore the primary treatment of IBS to minimize its effects on QoL and reduce the burden on medical resources.

\section{Conclusions}

This literature review discussed the pharmacological and non-pharmacological treatment strategies for IBS based on previous studies. Based on our findings, we can conclude that the use of methods including CBT, anti-psychological medications, probiotics, and other approaches such as acupuncture, anise, and diet modifications can help control the symptoms of IBS and improve the QOL of patients.

\section{Additional Information \\ Disclosures}

Conflicts of interest: In compliance with the ICMJE uniform disclosure form, all authors declare the following: Payment/services info: All authors have declared that no financial support was received from any organization for the submitted work. Financial relationships: All authors have declared that they have no financial relationships at present or within the previous three years with any organizations that might have an interest in the submitted work. Other relationships: All authors have declared that there are no other relationships or activities that could appear to have influenced the submitted work.

\section{Acknowledgements}

We would like to thank Hassan Tohid, neuroscientist and TEDx speaker, California Institute of Behavioral Neurosciences and Psychology, for his valuable contributions.

\section{References}


1. Knight JR, Locke GR 3rd, Zinsmeister AR, Schleck CD, Talley NJ: Family history of mental illness or alcohol abuse and the irritable bowel syndrome. J Psychosom Res. 2015, 78:237-241.

10.1016/j.jpsychores.2014.11.021

2. Bashashati M, Rezaei N, Shafieyoun A, et al.: Cytokine imbalance in irritable bowel syndrome: a systematic review and meta-analysis. Neurogastroenterol Motil. 2014, 26:1036-1048. 10.1111/nmo.12358

3. Rana SV, Sharma S, Sinha SK, Parsad KK, Malik A, Singh K: Pro-inflammatory and anti-inflammatory cytokine response in diarrhoea-predominant irritable bowel syndrome patients. Trop Gastroenterol. 2012, 33:251-256. 10.7869/tg.2012.66

4. Guilarte M, Santos J, de Torres I, et al.: Diarrhoea-predominant IBS patients show mast cell activation and hyperplasia in the jejunum. Gut. 2007, 56:203-209. 10.1136/gut.2006.100594

5. Vivinus-Nébot M, Frin-Mathy G, Bzioueche H, et al.: Functional bowel symptoms in quiescent inflammatory bowel diseases: role of epithelial barrier disruption and low-grade inflammation. Gut. 2014, 63:744-752. 10.1136/gutjnl-2012-304066

6. Ahn JY, Lee $\mathrm{KH}$, Choi $\mathrm{CH}$, et al.: Colonic mucosal immune activity in irritable bowel syndrome: comparison with healthy controls and patients with ulcerative colitis. Dig Dis Sci. 2014, 59:1001-1011. 10.1007/s10620013-2930-4

7. Holliday EG, Attia J, Hancock S, et al.: Genome-wide association study identifies two novel genomic regions in irritable bowel syndrome. Am J Gastroenterol. 2014, 109:770-772. 10.1038/ajg.2014.56

8. Wouters MM, Lambrechts D, Knapp M, et al.: Genetic variants in CDC42 and NXPH1 as susceptibility factors for constipation and diarrhoea predominant irritable bowel syndrome. Gut. 2014, 63:1103-1111. 10.1136/gutjinl-2013-304570

9. Zhou Q, Zhang B, Verne GN: Intestinal membrane permeability and hypersensitivity in the irritable bowel syndrome. Pain. 2009, 146:41-46. 10.1016/j.pain.2009.06.017

10. Shulman RJ, Jarrett ME, Cain KC, Broussard EK, Heitkemper MM: Associations among gut permeability, inflammatory markers, and symptoms in patients with irritable bowel syndrome. J Gastroenterol. 2014, 49:1467-1476. 10.1007/s00535-013-0919-6

11. Spiller R, Aziz Q, Creed F, et al.: Guidelines on the irritable bowel syndrome: mechanisms and practical management. Gut. 2007, 56:1770-1798. 10.1136/gut.2007.119446

12. Whitehead WE, Palsson O, Jones KR: Systematic review of the comorbidity of irritable bowel syndrome with other disorders: what are the causes and implications?. Gastroenterology. 2002, 122:1140-1156. 10.1053/gast.2002.32392

13. Heymen S, Maixner W, Whitehead WE, Klatzkin RR, Mechlin B, Light KC: Central processing of noxious somatic stimuli in patients with irritable bowel syndrome compared with healthy controls. Clin J Pain. 2010, 26:104-109. 10.1097/AJP.0b013e3181bff800

14. Maxion-Bergemann S, Thielecke F, Abel F, Bergemann R: Costs of irritable bowel syndrome in the UK and US. Pharmacoeconomics. 2006, 24:21-37. 10.2165/00019053-200624010-00002

15. Lackner JM, Jaccard J, Keefer L, et al.: Improvement in gastrointestinal symptoms after cognitive behavior therapy for refractory irritable bowel syndrome. Gastroenterology. 2018, 155:47-57. 10.1053/j.gastro.2018.03.063

16. Reme SE, Stahl D, Kennedy T, Jones R, Darnley S, Chalder T: Mediators of change in cognitive behaviour therapy and mebeverine for irritable bowel syndrome. Psychol Med. 2011, 41:2669-2679. 10.1017/S0033291711000328

17. Jang AL, Hwang SK, Kim DU: The effects of cognitive behavioral therapy in female nursing students with irritable bowel syndrome: a randomized trial. Eur J Gastroenterol Hepatol. 2014, 26:918-926. 10.1097/MEG.0000000000000140

18. Chilcot J, Moss-Morris R: Changes in illness-related cognitions rather than distress mediate improvements in irritable bowel syndrome (IBS) symptoms and disability following a brief cognitive behavioural therapy intervention. Behav Res Ther. 2013, 51:690-695. 10.1016/j.brat.2013.07.007

19. Ljótsson B, Hesser H, Andersson E, et al.: Mechanisms of change in an exposure-based treatment for irritable bowel syndrome. J Consult Clin Psychol. 2013, 81:1113-1126. 10.1037/a0033439

20. Ljótsson B, Falk L, Vesterlund AW, et al.: Internet-delivered exposure and mindfulness based therapy for irritable bowel syndrome--a randomized controlled trial. Behav Res Ther. 2010, 48:531-539. 10.1016/j.brat.2010.03.003

21. Kaplan A, Franzen MD, Nickell PV, Ransom D, Lebovitz PJ: An open-label trial of duloxetine in patients with irritable bowel syndrome and comorbid generalized anxiety disorder. Int J Psychiatry Clin Pract. 2014, 18:11-15. 10.3109/13651501.2013.838632

22. Sohn W, Lee OY, Kwon JG, et al.: Tianeptine vs amitriptyline for the treatment of irritable bowel syndrome with diarrhea: a multicenter, open-label, non-inferiority, randomized controlled study. Neurogastroenterol Motil. 2012, 24:860. 10.1111/j.1365-2982.2012.01945.x

23. Abdul-Baki H, El Hajj II, Elzahabi L, et al.: A randomized controlled trial of imipramine in patients with irritable bowel syndrome. World J Gastroenterol. 2009, 15:3636-3642. 10.3748/wjg.15.3636

24. Ladabaum U, Sharabidze A, Levin TR, et al.: Citalopram provides little or no benefit in nondepressed patients with irritable bowel syndrome. Clin Gastroenterol Hepatol. 2010, 8:42-48. 10.1016/j.cgh.2009.09.008

25. Masand PS, Pae CU, Krulewicz S, Peindl K, Mannelli P, Varia IM, Patkar AA: A double-blind, randomized, placebo-controlled trial of paroxetine controlled-release in irritable bowel syndrome. Psychosomatics. 2009, 50:78-86. 10.1176/appi.psy.50.1.78

26. Talley NJ, Kellow JE, Boyce P, Tennant C, Huskic S, Jones M: Antidepressant therapy (imipramine and citalopram) for irritable bowel syndrome: a double-blind, randomized, placebo-controlled trial. Dig Dis Sci. 2008, 53:108-115. 10.1007/s10620-007-9830-4

27. Tack J, Broekaert D, Fischler B, Van Oudenhove L, Gevers AM, Janssens J: A controlled crossover study of the selective serotonin reuptake inhibitor citalopram in irritable bowel syndrome. Gut. 2006, 55:1095-1103. 10.1136/gut.2005.077503

28. Ishaque SM, Khosruzzaman SM, Ahmed DS, Sah MP: A randomized placebo-controlled clinical trial of a 
multi-strain probiotic formulation (Bio-Kult ${ }^{\circledR}$ ) in the management of diarrhea-predominant irritable bowel syndrome. BMC Gastroenterol. 2018, 18:71. Accessed: April 15, 2020: https://bmcgastroenterol.biomedcentral.com/articles/10.1186/s12876-018-0788-9. 10.1186/s12876-0180788-9

29. Staudacher HM, Whelan K: Altered gastrointestinal microbiota in irritable bowel syndrome and its modification by diet: probiotics, prebiotics and the low FODMAP diet. Proc Nutr Soc. 2016, 75:306-318. 10.1017/S0029665116000021

30. Pinto-Sanchez MI, Hall GB, Ghajar K, et al.: Probiotic Bifidobacterium longum NCC3001 reduces depression scores and alters brain activity: a pilot study in patients with irritable bowel syndrome. Gastroenterology. 2017, 153:448-459. 10.1053/j.gastro.2017.05.003

31. Hod K, Sperber AD, Ron Y, et al.: A double-blind, placebo-controlled study to assess the effect of a probiotic mixture on symptoms and inflammatory markers in women with diarrhea-predominant IBS.

Neurogastroenterol Motil. 2017, 29:10.1111/nmo.13037

32. Han K, Wang J, Seo JG, Kim H: Efficacy of double-coated probiotics for irritable bowel syndrome: a randomized double-blind controlled trial. J Gastroenterol. 2017, 52:432-443. 10.1007/s00535-016-1224-yf

33. Begtrup LM, de Muckadell OB, Kjeldsen J, Christensen RD, Jarbøl DE: Long-term treatment with probiotics in primary care patients with irritable bowel syndrome--a randomised, double-blind, placebo controlled trial. Scand J Gastroenterol. 2013, 48:1127-1135. 10.3109/00365521.2013.825314

34. Enck P, Zimmermann K, Menke G, Klosterhalfen S: Randomized controlled treatment trial of irritable bowel syndrome with a probiotic E.-coli preparation (DSM17252) compared to placebo. Z Gastroenterol. 2009, 47:209-214. 10.1055/s-2008-1027702

35. Eswaran SL, Chey WD, Han-Markey T, Ball S, Jackson K: A randomized controlled trial comparing the low FODMAP diet vs. modified NICE guidelines in US adults with IBS-D. Am J Gastroenterol. 2016, 111:18241832. 10.1038/ajg.2016.434

36. Mosaffa-Jahromi M, Lankarani KB, Pasalar M, Afsharypuor S, Tamaddon AM: Efficacy and safety of enteric coated capsules of anise oil to treat irritable bowel syndrome. J Ethnopharmacol. 2016, 194:937-946. 10.1016/j.jep.2016.10.083

37. Abbasnezhad A, Amani R, Hajiani E, Alavinejad P, Cheraghian B, Ghadiri A: Effect of vitamin D on gastrointestinal symptoms and health-related quality of life in irritable bowel syndrome patients: a randomized double-blind clinical trial. Neurogastroenterol Motil. 2016, 28:1533-1544. 10.1111/nmo.12851

38. MacPherson H, Tilbrook H, Bland JM, et al.: Acupuncture for irritable bowel syndrome: primary care based pragmatic randomised controlled trial. BMC Gastroenterol. 2012, 12:150. Accessed: April 15, 2020: https://bmcgastroenterol.biomedcentral.com/articles/10.1186/1471-230X-12-150. 10.1186/1471-230X-12150

39. Zheng L, Lai Y, Lu W, et al.: Pinaverium reduces symptoms of irritable bowel syndrome in a multicenter, randomized, controlled trial. Clin Gastroenterol Hepatol. 2015, 13:1285-1292. 10.1016/j.cgh.2015.01.015 